\title{
Short Communication: Proportion faunal assemblage of rodents in geoecological districts of Mordovia, Russia
}

\author{
ALEXEY ANDREYCHEV \\ Department of Zoology, National Research Mordovia State University. Bolshevistskaya st., 68, Saransk 430005, Russia. Tel./fax.: +7-342-322637, \\ •email: teriomordovia@bk.ru
}

Manuscript received: 26 March 2016. Revision accepted: 6 August 2020.

\begin{abstract}
Andrechev A. 2020. Short Communication: Proportion faunal assemblage of rodents in geoecological districts of Mordovia, Russia. Biodiversitas 21: 3961-3968. In one natural area, animals may have different distribution. They inhabit some areas, while they do not exist. Scientists have been working on this issue for a long time. This study reports that the species composition and species distribution varies depending on geoecological districts. Twenty-eight rodent species have been recorded in the territory of Mordovia, Russia. In the region, the largest number of species belongs to coniferous and broad-leaved forests (42.9\%). Species widely distributed in several natural areas $(28.5 \%)$ ranked second place in terms of their representation. They are slightly inferior to the steppe animal species $(25 \%)$. The taiga fauna is represented by only $3.6 \%$ of the total number of registered species. For each geoecological district, the features of the rodent fauna are given, and rare species are identified. The forest-steppe region of Mordovia is compared in rodent fauna with other regions of Russia with different typical faunal assemblages.
\end{abstract}

Keywords: Habitat, population, rodents, Russia, species

\section{INTRODUCTION}

A review of the literature on small mammals, mostly rodents, suggests that average population density is highly determined by a balance of the positive effects of resources and the negative effects of enemies and the fact that the strengths of these effects vary depending on habitats. But there is also the density-independent population regulation. Seasonal patterns of population dynamics occur each year because of seasonal breeding and variations in mortality rates. Differences among years occur because of shifts in weather, resources, and enemies (Mapelli et al. 2012; Saetnan et al. 2012; Santos-Filho et al. 2012; Leon et al 2013; Lobo and Millar 2013; Batzli 2014; Gasperini et al. 2016; Pitelka and Batzli 2018). Understanding the spatial species' distribution sheds light on the group's biogeographical history, offers clues to the diversity drivers, and helps to guide conservation strategies (Maestri and Patterson 2016). However, the abundance and species composition of rodents depend highly on the landscape zone. Therefore, in this paper, we adhere to the term faunal assemblage (Stroud et al. 2015). They propose that the clearest and most comprehensive definition of assemblage should be «a taxonomically related group of species that occur together in space and time» (Stroud et al. 2015).

In Mordovia, studies of mammalian fauna are associated with the period of expedition research of academician Peter Simon Pallas in 1768-1774. For the first time, P.S. Pallas reported on the speckled ground squirrel (Spermophilus suslicus) found in Mordovia. In the $2^{\text {nd }}$ part of the message of the Academy of Sciences «Travels to different provinces of the Russian state», the scientist described in details the habitat of this species: «Gophers are found everywhere along the rivers Pyana and Sura, but not so often; from there, the further South and East, more often». In the initial review work on birds and mammals of the middle and lower Volga valley, M. N. Bogdanov (1871) gave the first mention of 35 species of mammals from the modern territory of Mordovia. Before the formation of the Mordovian Autonomous region (1930), data on some new mammal species for this region were reported for the territories of four provinces: Tambov, Nizhny Novgorod, Penza, and Simbirsk, some of which were part of modern Mordovia. Subsequently, the mammal fauna of the region was updated with information about new species.

In this paper, we present new information on the rodent fauna of the Mordovia, identify the distribution of these species along with the geoecological districts in the study area.

\section{MATERIALS AND METHODS}

Republic of Mordovia is located in the center of the European part of the Russian Federation. Its extreme borders are defined by geographical coordinates $42^{\circ} 11^{\prime}-46^{\circ}$ $45^{\prime} \mathrm{E}$ and $53^{\circ} 38^{\prime}-55^{\circ} 11^{\prime} \mathrm{N}$ (Figure 1). The maximum distance from west to east is $298 \mathrm{~km}$ and the distance from north to south is between 57 and $140 \mathrm{~km}$. The area of the Republic of Mordovia is $26.200 \mathrm{~km}^{2}$. Features of the geological structure of Mordovia are determined by its location in the central part of the Russian plain and the north-western slopes of the Volga Upland. In the western 
part of the Republic of Mordovia, the Volga Upland reaches the Oka-Don Lowland.

The climate of the region is moderately continental with pronounced seasons throughout the year. The average annual air temperature varies from 3.5 to $4.0^{\circ} \mathrm{C}$. The average temperature of the coldest month (January) is between -11.5 and $-12.3{ }^{\circ} \mathrm{C}$. Temperature declines to -47 ${ }^{\circ} \mathrm{C}$ are occurred. The average temperature of the warmest month (July), is between +18.9 and $+19.8{ }^{\circ} \mathrm{C}$. Extreme summer temperature values reach $37^{\circ} \mathrm{C}$. In Mordovia, the average annual precipitation is $480 \mathrm{~mm}$. Flora of the Republic of Mordovia is represented by 1448 species including 1411 angiosperms, 18 ferns, 7 horsetails, 6 lycophytes, 6 conifers (Silaeva et al. 2010, 2019).

All eleven geoecological districts of Mordovia belong to three types of landscapes (Yamashkin 2001). Landscapes of broadleaf forests and forest-steppes of erosiondenudation plains include Insarskiy, Vostochniy, and Yugo-Vostochniy geoecological districts. The landscape is characterized by a strongly eroded elevated terrain, where the arc-shaped watershed of rivers Sura and Alatyr is clearly distinguished. A typical feature of the terrain is the spread of steep slopes. Landscapes of broadleaf forests and forest-steppes of secondary morainic plains of the Volga upland include Yuzhniy, Moksha-Vadskiy, Issa-SivinskyRudninsky and Menya-P'yanskiy geoecological districts. A characteristic feature of this landscape is a well-defined slope change of natural territorial assemblage from watersheds to the valleys of medium-size rivers. Landscapes of mixed forests of water-glacial plains of the Oka-Don lowland and valleys of large rivers include Mokshinskiy, Vadskiy, Prialatyrskiy, and Surskiy geoecological districts. Water-glacial plains composed of sand with thin layers of loam. Groundwaters have a sporadic distribution. They are located at different depths. It causes a large mosaic in the degree of moisture content of natural assemblage. Features of the zonal position determine the presence of steppe and taiga elements here.

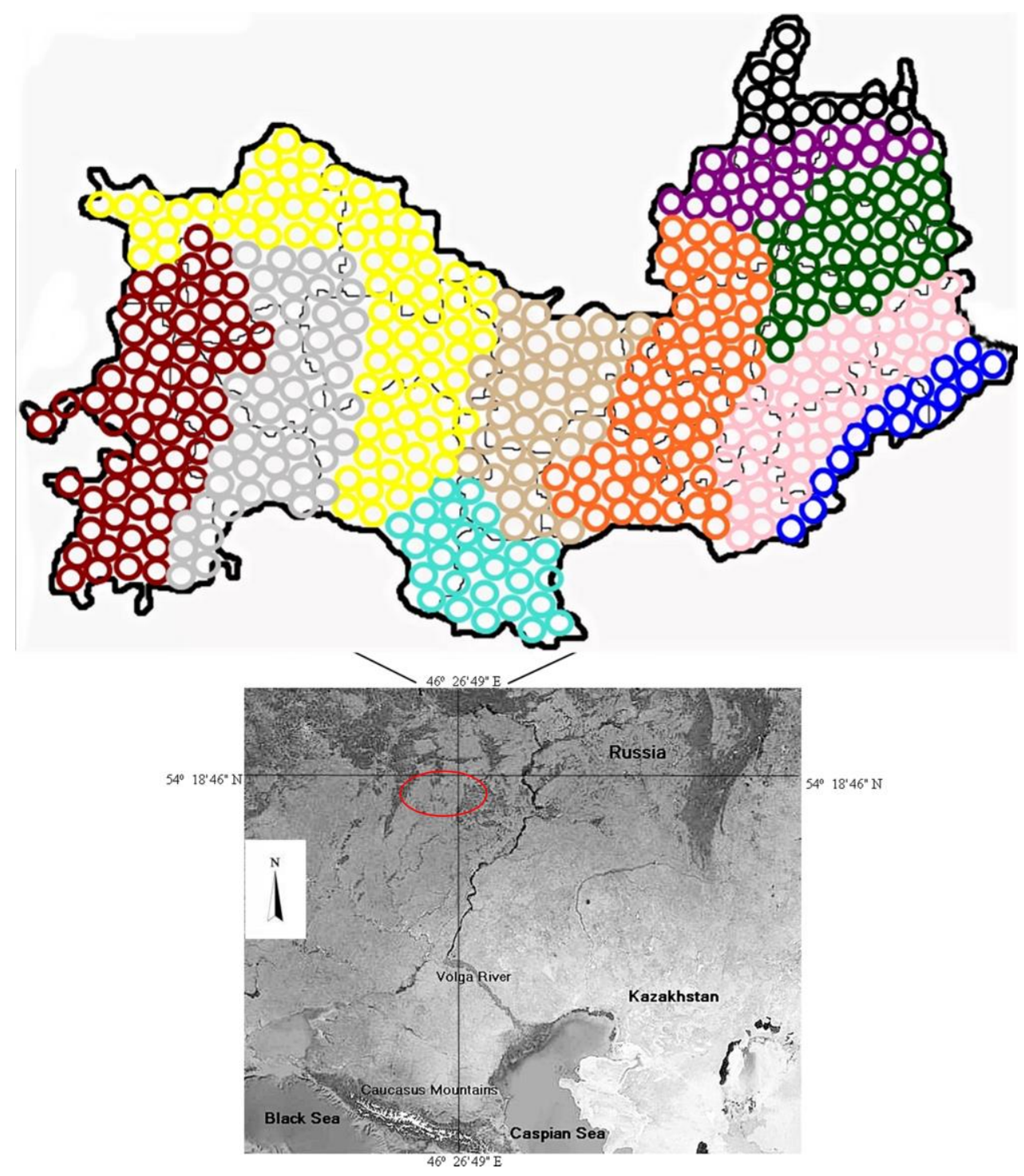

Figure 1. Location of geoecological districts in Mordovia, Russia (red oval: where animals were trapped). Note: red circle: Vadskiy district, yellow circle: Mokshinskiy district, grey circle: Moksha-Vadskiydistrict, blue circle: Yuzhniy district, brown circle: IssaSivinsko-Rudninskiy district, orange circle: Insarskiy district, purple circle: Prialatyrskiy district, green circle: Vostochniy district, pink circle: Yugo-vostochniy district, dark blue circle: Surskiy district, black circle: Menya-P'yanskiy district 
The material for this study was registered using the captures and visual registrations of rodents, as well as the collection of pellets of bird of prey (Bubo bubo, 585 pellets, Strix uralensis, 146 pellets, Aquila heliaca, 74 pellets) in the Republic of Mordovia. The material was collected during expedition and stationary research in different districts of Mordovia in 2006-2019. In the geoecological districts, for the highest coverage of the species composition, the following habitats were selected to study: (i) mixed forest; (ii) oak wood; (iii) aspen forest; (iv) meadow; (v) agricultural field; (vi) swamp; (vii) human construction.

The rodent species were identified using E.A. Schwartz (1989) (Table 1). Latin names of species are given according to Wilson and Reeder (2005). Based on these studies, taking into account the ranges of rodent species, the representation of various faunal assemblages along the geoecological districts of Mordovia was determined.

\section{RESULTS AND DISCUSSION}

In Mordovia, 28 rodent species were recorded (Andreychev et al. 2014, 2016; Andreychev and Lapshin 2017). Of these, in the region, the highest number of species is found in coniferous and broad-leaved forests $(42.9 \%)$. In the second place in terms of representation are species widely distributed in several natural areas $(28.5 \%)$. In terms of number of species, they are slightly inferior to steppe species $(25 \%)$. The taiga type of fauna is represented by only $3.6 \%$ of the total number of registered species. In geoecological districts, the distribution of species is not even (Figure 2).

In the Insarskiy geoecological district, the analysis of the rodent species composition for belonging to the fauna types showed a considerable number of representatives of widespread in several natural zones of the steppe faunal assemblage $(42.9 \%)$. Species of coniferous and broadleaved forests $(35.7 \%)$ and steppe faunal assemblages $(21.4 \%)$ were less represented. Among the representatives of the steppe faunal complex, three species (Marmota bobak, Spermophilus suslicus, Spalax microphthalmus) are rare (Figure 3) not only in the district, but also in the whole of Mordovia (Andreychev et al. 2015; Andreychev 2018, 2019). Only in this area, the settlements of the blind mole rat $S$. microphthalmus are concentrated. Here its population has a vulnerable state, as in other parts of its range (Zagorodniuk et al. 2018). The Eurasian harvest mouse has the highest number of locations in this district compared to other ones.

In Vostochniy geoecological district, the dominants in terms of faunal types are species widely distributed in several natural zones $(50 \%)$. The second position in terms of number is occupied by species preferring coniferous and broad-leaved forest $(41.7 \%)$. The least represented species are assigned to the steppe faunal complex (8.3\%). This district has habitats suitable for steppe species such as the bobak marmot, speckled ground squirrel, and great jerboa. For the bobak marmot, grazing impact is important, as it was shown in Ukraine (Rashevska and Semeniuk 2015; Tokarsky 2015; Savchenko and Ronkin 2018).

In the Yugo-Vostochniy geoecological district, the rodent species composition was characterized by a relatively high number of representatives of the steppe faunal complex $(24.9 \%)$. These are the following species: bobak marmot, speckled ground squirrel, great jerboa, common hamster. This district has the highest concentration of settlements and the largest population of bobak marmot in Mordovia. Species widely distributed in several natural zones $(43.8 \%)$ are predominated over species of coniferous-deciduous forests (31.3\%).

In Yuzhniy and Moksha-Vadskiy geoecological districts, we found an equal ratio of species groups widely distributed in several natural zones $(50 \%)$ and living in coniferous and broad-leaved forests (50\%). Steppe and taiga species are not found here.

According to the rodent fauna structure, Issa-SivinskyRudninsky geoecological district is distinguished by the predominance of widespread species in several natural zones $(50 \%)$ and species of coniferous and broad-leaved forests $(42.5 \%)$. One of the rare representatives preferring coniferous-deciduous forests in this district area is the hazel dormouse. The species of the steppe faunal complex accounted for about $7.5 \%$.

In relation to the faunal assemblage, Menya-P'yanskiy district is represented by two predominant groups of species widely distributed in several natural zones (45\%) and living in coniferous-deciduous forests $(37 \%)$. The steppe fauna type contains $18 \%$ species. Here, on the border with the Nizhniy Novgorod oblast, the bobak marmot is known.

The analysis of rodent species registered in the Mokshinskiy district, belonging to the fauna types, showed their heterogeneity. Rodents of coniferous and broadleaved forests $(50 \%)$ were represented by the highest number of species. The proportions of representatives of the other three fauna types are distributed as follows: widespread species (31.8\%), steppe (13.6\%), and taiga $(4.6 \%)$. In this region, the taiga fauna is represented by the red vole, which is a quite rare species. The high species diversity of rodents ( 22 species) in this district is caused by the presence of a high number of Protected Areas. First of them is the Mordovia State Nature Reserve where the following rare species are registered: forest dormouse, edible dormouse, garden dormouse, grey hamster, steppe lemming, Northern birch mouse, harvest mouse, Eurasian beaver.

The Vadskiy geoecological district is dominated by widespread species (46.6\%) and coniferous-deciduous forests $(46.6 \%)$. The district area is almost completely covered with forest. For this reason, there is a high number of species such as the bank vole, yellow-necked mouse, Ural field mouse, and red squirrel. Due to the dense network of forest rivers and lakes, a high number of Eurasian beaver populations is known here (Andreychev 2017). Due to the almost complete absence of biotopes preferred by steppe species, their representation here is minimal $(6.8 \%)$. 
Table 1. The species composition of rodents in Mordovia, Russia belonging to faunal assemblages

\begin{tabular}{|c|c|c|c|}
\hline \multirow[b]{2}{*}{ Taiga } & \multicolumn{3}{|c|}{ Faunal assemblage } \\
\hline & Coniferous and broadleaf forests & Steppe & $\begin{array}{l}\text { Widely distributed in } \\
\text { several natural areas }\end{array}$ \\
\hline \multirow[t]{15}{*}{$\begin{array}{l}\text { Clethrionomys rutilus } \\
\text { (Pallas, 1779), northern } \\
\text { red-backed vole }\end{array}$} & $\begin{array}{l}\text { Clethrionomys glareolus (Schreber, 1780), } \\
\text { bank vole }\end{array}$ & $\begin{array}{l}\text { Spermophilus suslicus } \\
\text { (Güldenstaedt, 1770), } \\
\text { Speckled ground squirrel }\end{array}$ & $\begin{array}{l}\text { Sciurus vulgaris (Linnaeus, } \\
\text { 1758), Eurasian red squirrel }\end{array}$ \\
\hline & $\begin{array}{l}\text { Microtus arvalis (Pallas, 1779), common } \\
\text { vole }\end{array}$ & $\begin{array}{l}\text { Spalax microphthalmus } \\
\text { (Güldenstaedt, 1770) greater } \\
\text { mole rat }\end{array}$ & $\begin{array}{l}\text { Arvicola terrestris (Linnaeus, } \\
\text { 1758), European water vole }\end{array}$ \\
\hline & $\begin{array}{l}\text { Microtus agrestis (Linnaeus, 1761), field } \\
\text { vole }\end{array}$ & $\begin{array}{l}\text { Marmota bobak (Müller, } \\
\text { 1776), bobak marmot }\end{array}$ & $\begin{array}{l}\text { Microtus oeconomus (Pallas, } \\
1776), \text { root vole }\end{array}$ \\
\hline & Pitymys subterraneus (de Selys- & Lagurus lagurus (Pallas, & Ondatra zibethicus (Linnaeus, \\
\hline & Longchamps, 1836), European pine vole & 1773), steppe lemming & 1766), muskrat \\
\hline & $\begin{array}{l}\text { Castor fiber (Linnaeus, 1758), Eurasian } \\
\text { beaver }\end{array}$ & $\begin{array}{l}\text { Cricetulus migratorius } \\
\text { (Pallas, 1773), grey hamster }\end{array}$ & $\begin{array}{l}\text { Mus musculus (Linnaeus, } \\
1758) \text {, house mouse }\end{array}$ \\
\hline & Dryomys nitedula (Pallas, 1779), forest & Cricetus cricetus (Linnaeus, & Micromys minutus (Pallas, \\
\hline & dormouse & 1758), common hamster & 1771), Eurasian harvest mouse \\
\hline & $\begin{array}{l}\text { Eliomys quercinus (Linnaeus, 1766), } \\
\text { garden dormouse }\end{array}$ & $\begin{array}{l}\text { Allactaga major }(\text { Kerr, } \\
1792), \text { great jerboa }\end{array}$ & $\begin{array}{l}\text { Apodemus agrarius (Pallas, } \\
1771 \text { ), striped field mouse }\end{array}$ \\
\hline & $\begin{array}{l}\text { Muscardinus avellanarius (Linnaeus, } \\
1758), \text { hazel dormouse }\end{array}$ & & $\begin{array}{l}\text { Rattus norvegicus } \\
\text { (Berkenhout, 1769), brown rat }\end{array}$ \\
\hline & Glis glis (Linnaeus, 1766), edible & & \\
\hline & dormouse & & \\
\hline & $\begin{array}{l}\text { Sicista betulina (Pallas, 1779), northern } \\
\text { birch mouse }\end{array}$ & & \\
\hline & $\begin{array}{l}\text { Apodemus uralensis (Pallas, 1811) Ural } \\
\text { field mouse }\end{array}$ & & \\
\hline & $\begin{array}{l}\text { Apodemus flavicollis (Melchior, 1834), } \\
\text { vellow-necked mouse }\end{array}$ & & \\
\hline
\end{tabular}

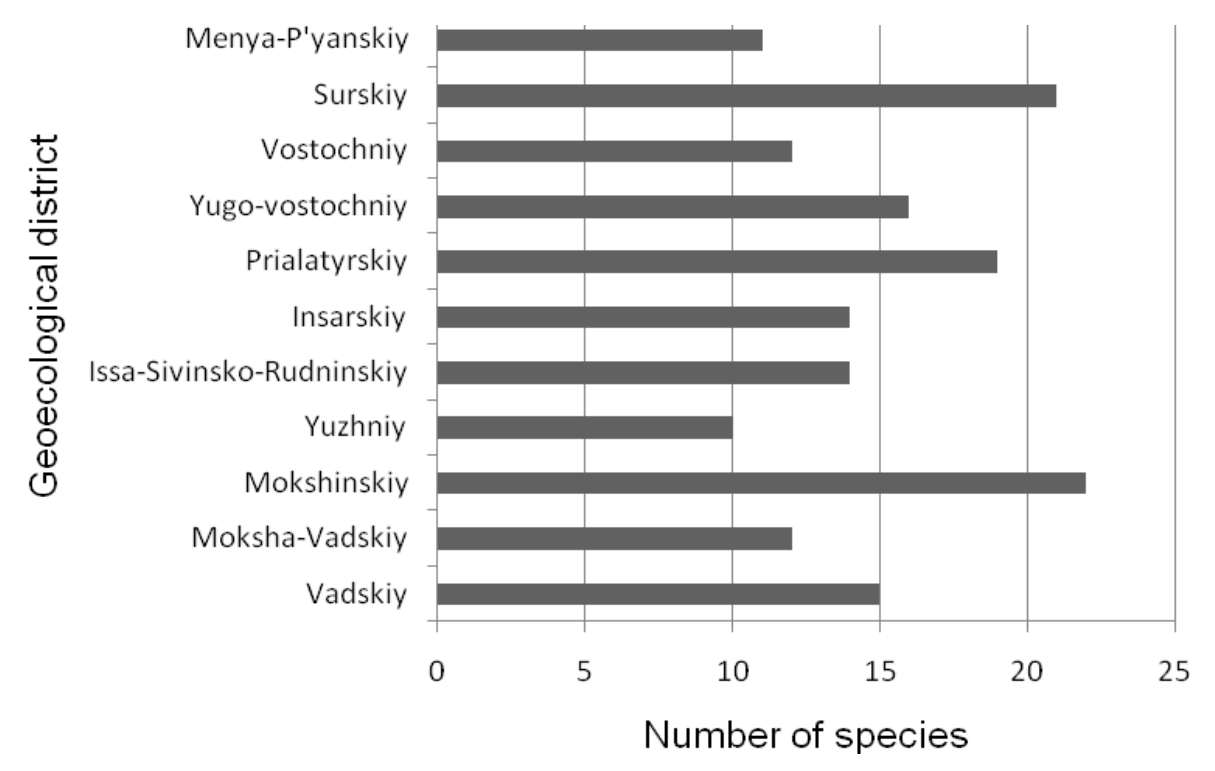

Figure 2. Number of rodent species in the geoecological districts of Mordovia, Russia 

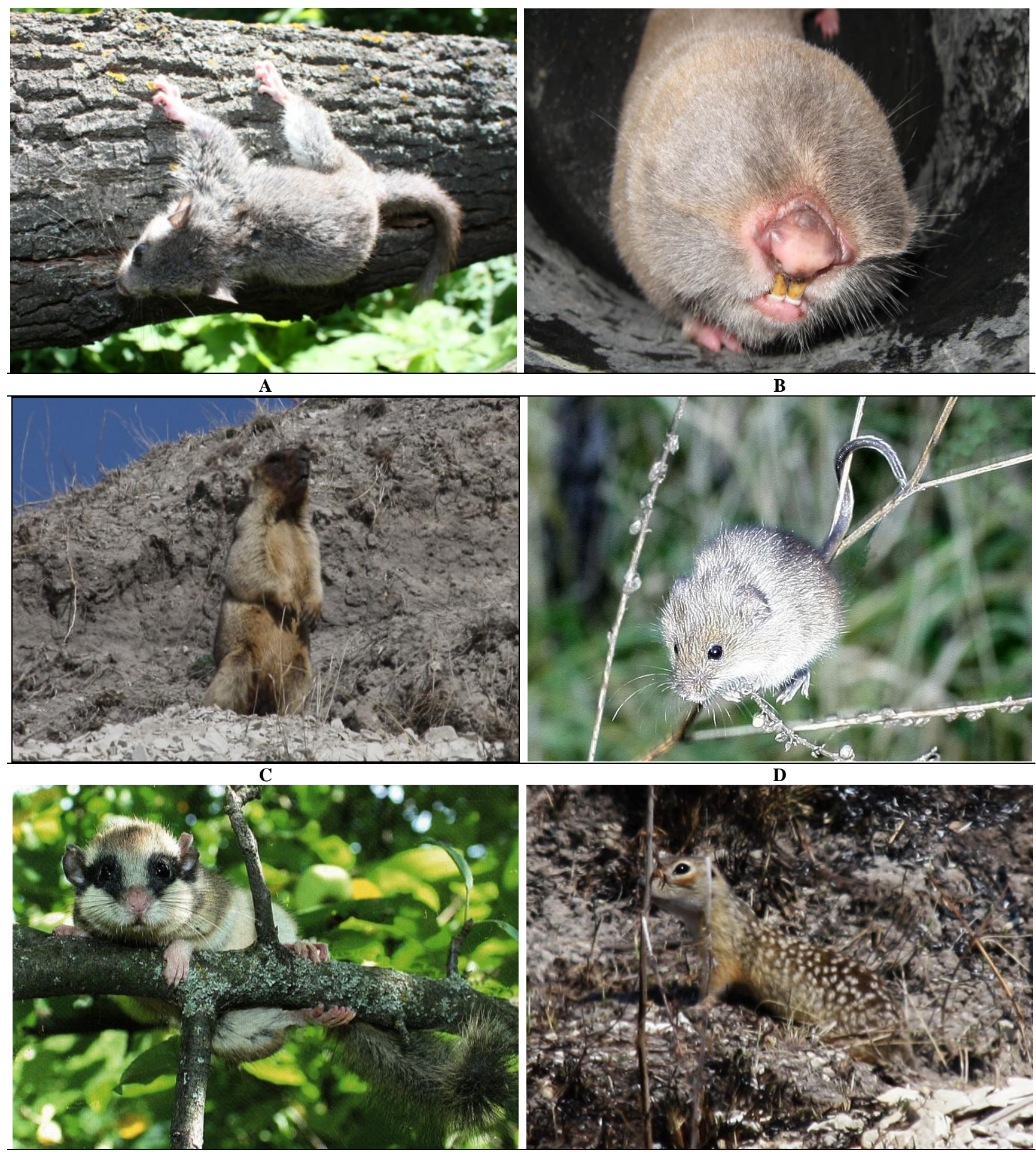

$\mathbf{E}$

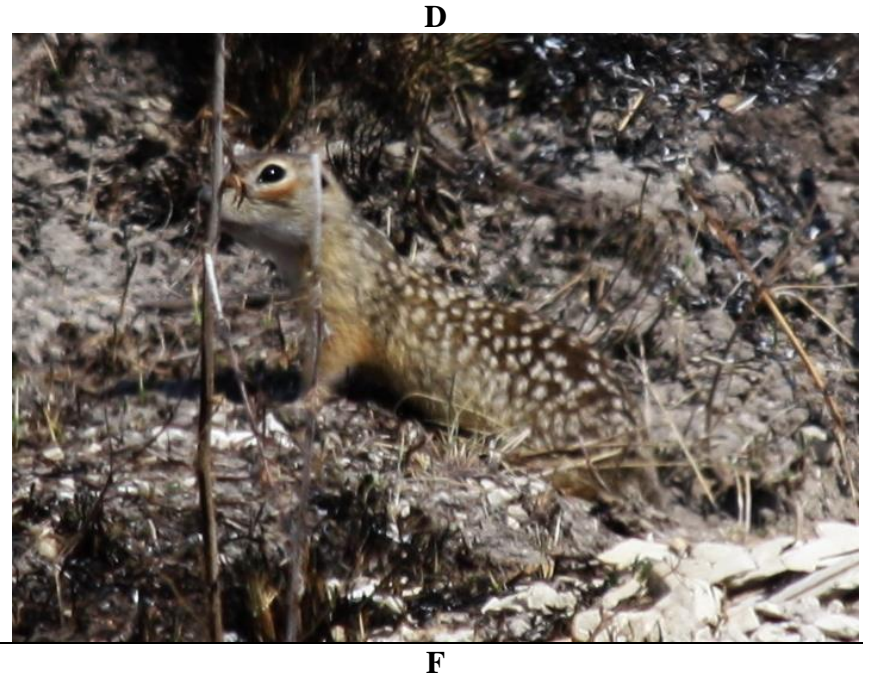

Figure 3. Photo of rare rodents in Mordovia, Russia. A. Edible dormouse (Glis glis); B. Greater mole rat (Spalax microphthalmus); C. Bobak marmot (Marmota bobak); D. Eurasian harvest mouse (Micromys minutus); E. Forest dormouse (Dryomys nitedula); F. Speckled ground squirrel (Spermophilus suslicus). (Photographs by A. Andreychev)

In the Prialatyrskiy district, the complex of coniferousbroadleaf forest species is of great importance for belonging to the faunal types $(57.9 \%)$. This is the highest representation of this fauna type among all the geoecological districts in the Republic of Mordovia.
Species widespread in several natural zones account for $36.8 \%$. The steppe faunal complex is represented by $5.3 \%$ of rodent species. The district is characterized by the presence of many rare rodent species. It is home to Northern birch mouse, forest dormouse, hazel dormouse, 
edible dormouse, harvest mouse, Eurasian beaver. European pine vole (Pitymys subterraneus) was not registered in our catches. However, in 2019, it was captured for the first time in the Republic of Mordovia (Kirillova et al. 2019). We consider it appropriate to provide data on catches of this vole. One instance of an underground vole was captured on 4 May in an abandoned vegetable garden in the village Obrezki. This record testifies the easternmost occurrence of M. subterraneus. Previously, the underground vole was recorded in regions adjacent to Mordovia, namely in the vicinity of the village Zhelannoe in the Ryazan oblast and in the Zemetchinskiy district of the Penza oblast. This species is rare and included in many regional Red Data Books of Russia: Leningrad oblast (Red book 2002), Tver oblast (Viktorov and Istomin 2002), Penza oblast (Bystrakova 2019), Moscow oblast (Yemelyanova 2008), Pskov oblast (Istomin 2014), and Novgorod oblast (Doynikova 2015). The appearance of a species new for Mordovia can be explained by its range extension. This is confirmed by the registration of this new species in the Smolensk oblast, too (Belyaev 2020).

In the Surskiy geoecological district, coniferous and broad-leaved forest types predominate $(42.9 \%)$. To a lesser extent, there are species that are widely distributed in several natural areas of the forest $(33.3 \%)$ and the steppe faunal complex (23.8\%). This, Surskiy, riverine district, as well as Mokshinskiy, Prialatyrskiy district, also have a high species diversity. There are 21 species of rodents. Here, such rare species are noted: forest dormouse (Andreychev and Boyarova 2020; Andreychev and Kiyaykina 2020), hazel dormouse, great jerboa, bobak marmot, speckled ground squirrel, steppe lemming, Eurasian beaver, pygmy field mouse, harvest mouse.

Thus, our analysis of the proportions of faunal assemblages showed the highest representation of rodents in the geoecological districts of the landscape of mixed forests of the water-glacial plains of the Oka-Don lowland and the valleys of large rivers.

In discussing the results, it is of great interest to compare the distribution of the identified rodent species by faunal types in Mordovia with other regions of different natural zones, particularly, Saratov oblast, which belongs to the steppes of the European part of Russia. Thirty-two rodent species have been recorded in this region (Shlyakhtin et al. 2008). Of these, the highest number of species belongs to the steppe fauna type $(53.1 \%)$. The second type most represented by species are coniferous and broad-leaved forests (25\%). They are slightly inferior to the species widely distributed in several natural zones $(21.9 \%)$. Present diversity patterns of the studied steppe species suggest that they share a unique genetic signature; and distinct assemblages exist in each of the now isolated areas rich in steppe habitats (Kajtoch et al. 2016).

We compared the rodent fauna in Mordovia with the Vladimir oblast belonging to the zone of coniferous-broadleaved (mixed) forests. Twenty rodent species have been recorded in this region (Kuzmin and Serbin 1998). Of them, the highest number of species is found in coniferous and broad-leaved forests (55\%). Species widely distributed in several natural areas (40\%) are ranked second place in terms of representation. The steppe fauna type is represented by only $5 \%$ of the total number of registered species. This region is similar to Mordovia in terms of the predominance of two fauna types. The difference is caused by the low diversity of steppe fauna compared to the lack of taiga fauna species compared to Mordovia. A similar situation was noted in mountain forest ecosystems of the Beskydy Mountains (Suchomel et al. 2014). The highest diversity was observed in primeval forests.

We compared the rodent fauna of Mordovia with Karelia belonging to the taiga. Twenty-two rodent species have been recorded in this region (Ivanter 2008). Of them, the highest number of species belongs to two fauna types, including widespread in several natural zones $(43 \%)$ and inhabiting coniferous and broad-leaved forests $(38 \%)$. The taiga fauna type is represented by $19 \%$ of the total number of registered species. Karelia is also similar to Mordovia in terms of the predominance of two fauna types. However, in Mordovia, a considerable predominance of fauna of coniferous and broad-leaved forests over the fauna of species widely distributed in several natural zones was revealed. A notable difference between the rodent fauna of Karelia is a high proportion of taiga species, compared with Mordovia. In Karelia, the responses to concentrated cuttings include a decrease in total population size, transition to an arrhythmic population dynamics with drastic short-term rises and deep long depressions, formation of unstable mosaic spatial distribution, disturbances of the reproduction rates, and a decrease in reproduction intensity (Ivanter and Kurhinen 2016). In Mordovia, concentrated cuttings are not produced. So, the total population size of insectivorous mammals is relatively stable. The biogeographical history of $M$. rutilus differs from other boreal forest-associated species. Welldifferentiated clades and the existence of secondary contact zones indicate prolonged isolation and persistence in Eurasian refugia (Kohli et al. 2015).

Thus, we want to emphasize the features of distinguishing Mordovia by the proportion of different assemblages. Firstly, this is the uniqueness of this region, where both steppe and taiga species are found. This is not related to many other regions. It is no coincidence that Mordovia is called a forest-steppe region. Secondly, it is a transitional zone between the steppe faunal assemblage and the faunal assemblage of coniferous and broadleaf forests. This is evidenced by the almost equal proportion of steppe species and species widely distributed in several natural areas.

In Mordovia, the proportion of rodent species of the total number of mammal species is $37 \%$. This is the highest indicator among other animal groups. Insectivores (16\%) (Andreychev 2020) are somewhat inferior to rodents. In comparison to Cisokan, Cianjur, West Java, Indonesia, the proportion of rodent species from other mammals is higher (Withaningsih et al. 2018; Husodo et al. 2019). This is a feature differing Mordovia of many other mammal faunas, where representatives of the other animal orders predominate (Wirdateti et al. 2013; Sulistyadi 2016; Medina et al. 2018; Shanidah et al. 2018). We assume that 
the geographic latitude of the area inhabited by rodent species may be decisive in this difference. Indisputable influence is exerted by climatic conditions. Our research covers the northern sections (ca. $54^{\circ} \mathrm{N}$ ), while in Indonesia these are the southern sections (ca. $6^{\circ} \mathrm{S}$ ), and in Peru these are the southern sections (ca. $10^{\circ} \mathrm{S}$ ). Thus, possible causes for the higher proportion of rodents in Mordovia are more severe living conditions, which are less suitable for bats.

\section{ACKNOWLEDGEMENTS}

I am grateful to E.A. Ilykaeva, A.V. Salaeva, E.O. Levtsova, S.A. Yutukova, M.N. Suharnikova for support in carrying out of field studies.

\section{REFERENCES}

Andreychev A. 2017. Population density of the Eurasian beaver (Castor fiber L.) (Castoridae, Rodentia) in the Middle Volga of Russia. For. Stud. 67: 109-115. DOI: 10.1515/fsmu-2017-0016

Andreychev AV. 2018. A new methodology for studying the activity of underground mammals. Biol. Bull. Russ. Acad. Sci. 45: 937-943. DOI: 10.1134/S1062359018080022.

Andreychev AV. 2019. Daily and seasonal feeding activity of the greater mole-rat (Spalax microphthalmus, Rodentia, Spalacidae). Biol Bull Russ Acad Sci 46 (9): 1172-1181. DOI 10.1134/S1062359019090012.

Andreychev A. 2020. Ecological and faunal complexes of insectivorous mammals of the Republic of Mordovia, Russia. Biodiversitas 21 (7) 3344-3349. DOI: 10.13057/biodiv/d210758

Andreychev A, Boyarova E. 2020. Forest dormouse (Dryomys nitedula, Rodentia, Gliridae) -a highly contagious rodent in relation to zoonotic diseases. For Ideas 26 (1): 262-269.

Andreychev AV, Kiyaykina OS. 2020. Homing in the forest dormouse (Dryomys nitedula, Rodentia, Gliridae). Zool Zhurnal 99 (6): 698705. DOI: $10.31857 /$ S0044513420060033

Andreychev AV, Lapshin, A.S. 2017: Quantitative and qualitative composition of diet of the Ural owl, Strix uralensi (Strigidae, Strigiformes), in the central part of European Russia (the example of the Republic of Mordovia). Vestn Zool 51 (5): 421-428. DOI: 10.1515/vzoo-2017-0050

Andreychev AV, Lapshin AS, Kuznetsov VA. 2014. Food spectrum of the Eagle owl (Bubo bubo) in the Republic of Mordovia. Zool Zhurnal 93 (2): 248-258. DOI: 10.7868/S0044513414020032.

Andreychev AV, Lapshin AS, Kuznetsov VA. 2016. Breeding success of the Eurasian eagle-owl (Bubo bubo) and rodent population dynamics. Biology Bulletin $43 \quad(8)$ : 851-861. DOI: 10.1134/S1062359016080045.

Andreychev AV, Zhalilov AB, Kuznetsov VA 2015. The state of local Steepe woodchuck (Marmota bobak) populations in the Republic of Mordovia. Zool Zhurnal 94 (6): 723-730. DOI: 10.7868/S004451341506033.

Batzli GO. 2014. Population Fluctuations in Rodents. J. Mammal. 95 (1):189-190. DOI: 10.1644/13-MAMM-R-195.

Belyaev DA. 2020. The European pine vole, Microtus subterraneus Selyslongchamps 1836 (Rodentia, Cricetidae), a mammal species new to the fauna of the Smolensk region. Zool Zhurnal 99 (2): 234-238. DOI: 10.31857/S0044513420020051.

Bogdanov MN. 1871. Birds and animals of the black earth zone of the Volga region and the valley of the Middle and Lower Volga. Proceedings of the society of naturalists at Kazan University 1: 229 . [Russian].

Bystrakova NV. 2019. Underground vole. Red book of the Penza region. Voronezh. 231. [Russian]

Doynikova OYu. 2015. The underground vole. Red data book of the Novgorod region. Saint Petersburg. 154. [Russian].

Emelyanova LG. 2008. Underground vole. Red book of the Moscow region. Moscow. 33. [Russian].
Gasperini S, Mortelliti A, Bartolommei P, Bonacchi A, Manzo E, Cozzolino R. 2016. Effects of forest management on density and survival in three forest rodent species. For Ecol Manag 382: 151-160. DOI: 10.1016/j.foreco.2016.10.014

Husodo T, Febrianto P, Megantara EN, Shanida SS, Pujianto MP. 2019. Diversity of mammals in forest patches of Cisokan, Cianjur, West Java, Indonesia. Biodiversitas 20 (5): 1281-1288.

Istomin AV. 2014. The underground vole. Red data book of the Pskov region. Pskov. 483. [Russian].

Ivanter EV. 2008. Mammals of Karelia. Peter GU Publishing house, Petrozavodsk. [Russian]

Ivanter EV, Kurhinen YP. 2016. The effect of commercial cuttings on faunal associations in taiga ecosystems: A case study of small mammals in eastern Fennoscandia. Biol Bull Russ Acad Sci 43 (4): 350-358. DOI: 10.1134/S106235901604004X.

Kajtoch L, Cieslak E, Varga Z, Paul W, Mazur MA, Sramko G, Kubisz D. 2016. Phylogeographic patterns of steppe species in Eastern Central Europe: A review and the implications for conservation. Biodivers Conserv 25 (12): 2309-2339. DOI: 10.1007/s10531-016-1065-2

Kirillova NYu, Krystufek B, Kirillov AA, Ruchin AB, Grishutkin GF. 2019. The first record of Microtus subterraneus (de SélysLongchamps, 1836) (Rodentia, Cricetidae) for Mordovia, Russia. Acta Biologica Sibirica 5 (4): 145-149. DOI: 10.14258/abs.v5.i4.7149 [Russian].

Kohli BA, Fedorov VB, Waltari E, Cook JA. 2015. Phylogeography of a Holarctic rodent (Myodes rutilus): testing high-latitude biogeographical hypotheses and the dynamics of range shifts. J Biogeogr 42 (2): 377-389. DOI: 10.1111/jbi.12433.

Kuzmin LL, Serbin VA. 1998. Catalog of Vertebrates of the Vladimir region. Vladimir. [Russian]

Leon VA, Fraschina J, Guidobono JS, Busch M. 2013. Habitat use and demography of Mus musculus in a rural landscape of Argentina. Integr Zool 8: 18-29. DOI: 10.1111/j.1749-4877.2012.00290.x.

Lobo N, Millar JS. 2013. Indirect and mitigated effects of pulsed resources on the population dynamics of a northern rodent. J Anim Ecol 82 (4): 814-825. DOI: 10.1111/1365-2656.12062

Maestri R, Patterson, BD. 2016. Patterns of species richness and turnover for the South American rodent fauna. PLoS One 11 (3). DOI: 10.1371/journal.pone.0151895.

Mapelli FJ, Mora MS, Mirol PM, Kittlein MJ. 2012. Effects of quaternary climatic changes on the phylogeography and historical demography of the Subterranean rodent Ctenomys porteousi. J Zool 286 (1): 48-57. DOI: 10.1111/j.1469-7998.2011.00849.x.

Medina CE, Díaz DR, Malaga BA, Medina YK, López E. 2018. Short communication: Second record of Eumops chiribaya (Chiroptera, Molossidae) in Peru. Biodiversitas 19 (6): 1979-1984.

Pitelka FA, Batzli GO, 2018. Demography and condition of Brown lemmings (Lemmus trimucronatus) during cyclic density fluctuations Near Barrow, Alaska. Ann Zool Fenn 55 (4-6):187-236. DOI: 10.5735/086.055.0605

Rashevska HV, Semeniuk SK. 2015. A unique colony of the Bobak marmot, Marmota bobak (Rodentia, Sciuridae), in steppes of the right-bank Ukraine. Vestn Zool 49 (4): 377-378. DOI: 10.1515/vzoo2015-0042

Red book of the Leningrad region: Animals. 2018. Saint-Petersburg. 559. [Russian].

Saetnan ER, Batzli GO, Skarpe C. 2012. Do sheep affect vole populations in alpine meadows of central Norway?. J Mammal 93 (5): 1283-1291. DOI: 10.1644/11-MAMM-A-226.1

Santos-Filho M, Peres CA, Da Silva DJ, Sanaiotti TM. 2012. Habitat patch and matrix effects on small-mammal persistence in Amazonian forest fragments. Biodivers Conserv 21 (4): 1127-1147. DOI: 10.1007/s10531-012-0248-8

Savchenko G, Ronkin V. 2018. Grazing, abandonment and frequent mowing influence the persistence of the Steppe marmot, Marmota bobak. Hacquetia 17 (1): 25-34. DOI: 10.1515/hacq-2017-0009

Shanidah SS, Partasasmita R, Hudoso T, Parikesit, Meganatara EN. 2018. Short Communication: Javan leopard cat (Prionailurus bengalensis javanensis Desmarest, 1816) in the Cisokan non-conservation forest areas, Cianjur, West Java, Indonesia. Biodiversitas 19 (1): 37-41.

Shlyakhtin GV, Zavyalov EV, Yakushev NN, Tabachishin VG, Anikin VV, Berezutsky MA, Koshkin VA. 2008. Biodiversity and nature protection in the Saratov region. Saratov. [Russian]

Silaeva TB, Kiryukhin IV, Chugunov GG, Levin VK, Mayorov SR, Pismarkina EV, Ageeva AM, Vargot EV. 2010. Vascular plants of the 
Republic of Mordovia (synopsis of flora). Publisher of the Mordovia State University, Saransk. [Russian]

Silaeva TB, Pismarkina EV, Ageeva AM, Ershkova EV, Kiryukhin IV, Khapugin AA, Chugunov GG. 2019. Materials for the flora of the Republic of Mordovia. Structure, dynamics and functioning of natural-social-production systems: science and practice. Saransk. 4655. [Russian].

Stroud JT, Bush MR, Ladd MC, Nowicki R J, Shantz AA, Sweatman J 2015. Is a community still a community? Reviewing definitions of key terms in community ecology. Ecol Evol 5 (21): 4757-4765. DOI: $10.1002 /$ ece 3.1651

Suchomel J, Purchart L, Cepelka L, Heroldova M. 2014. Structure and diversity of small mammal communities of mountain forests in Western Carpathians. Eur J For Res 133 (3): 481-490. DOI: 10.1007/s10342-013-0778-y.

Sulistyadi E. 2016. Characteristics of large mammals community in Bali Barat National Park (BBNP). Zoo Indon 25 (2): 142-159.

Tokarsky V. 2015. A pasture of big ungulate animals as key ecological factors influencing the fluctuation of natural habitat of steppe herbivorous mammals. Vestn Zool 49 (2): 159-170. DOI 10.1515/vzoo-2015-0018
Viktorov LV, Istomin AV. 2002. Mammals. Red book of the Tver region. Tver. 153-161. [Russian].

Wilson DE, Reeder DM. 2005. Mammal Species of the World, Third Edition. The Johns Hopkins University Press.

Withaningsih S, Noorahya F, Megantara EN, Parikesit, Husodo T. 2018. Nest existences and population of Pangolin (Manis javanica Desmarest, 1822) at the designated area of Cisokan Hydropower, West Java, Indonesia. Biodiversitas 19 (1): 153-162.

Wirdateti, Yulianto, Semiadi G. 2013. Distribution and habitat of Sunda pangolin (Manis javanica Desmarest, 1822) in the districts of Tanggamus and West Lampung, Lampung Province. Pros Sem Nas Masy Biodiv Indon 2: 181-186. [Indonesian]

Yamashkin AA. 2001. Geoecological analysis of the process of economic development of landscapes of Mordovia. Publisher of the Mordovia State University, Saransk. [Russian].

Zagorodniuk I, Korobchenko M, Parkhomenko V, Barkaszi Z. 2018. Steppe rodents at the edge of their range: A case study of Spalax microphthalmus in the north of Ukraine. Biosyst Divers 26 (3): 188200. DOI: $10.15421 / 011829$. 